\title{
West African Sahel has become wetter during the last 30 years, but dry spells are shorter and more frequent
}

\author{
Adeline Bichet*, Arona Diedhiou \\ Univ. Grenoble Alpes, IRD, CNRS, Grenoble INP, IGE, 38000 Grenoble, France
}

\begin{abstract}
Over the twentieth century, Sahel rainfall has undergone extreme variations on a decadal timescale. This study investigated the recent precipitation changes in West African Sahel using a high-resolution Climate Hazards Group InfraRed Precipitation with Station (CHIRPS) product over the period 1981-2014. We found that the recent increase in precipitation results principally from an increase in the number of wet days (+10 d compared to the normal) over the entire West African Sahel band, along with an increase in the precipitation intensity over the central part of the West African Sahel $\left(+3 \mathrm{~mm} \mathrm{~d}^{-1}\right)$. However, this overall increase in precipitation is associated with dry spells that are becoming more frequent but on average shorter over the entire West African Sahel band (on average by $30 \%$ ), and with precipitation intensity that is decreasing (around $3 \mathrm{~mm} \mathrm{~d}^{-1}$ during the study period) in the western part of the West African Sahel (Senegal). Such reorganization (i.e. weaker but more frequent precipitation) is expected to be beneficial for agriculture and society, reducing the likelihood of both flooding and droughts.
\end{abstract}

KEY WORDS: Precipitation - CHIRPS - Extreme variation $\cdot$ Senegal $\cdot$ Sahel recovery $\cdot$ Wet spells Isolated wet days $\cdot$ Trends $\cdot$ Variability

\section{INTRODUCTION}

Sahelian rainfall is scarce (around $500 \mathrm{~mm} \mathrm{yr}^{-1}$ ) and unevenly distributed across the year. Most of the yearly Sahelian precipitation falls during the rainy season in June-July-August-September (JJAS), when the intertropical convergence zone (ITCZ) is located northward (Sultan et al. 2003). Agriculture and livestock, which are the main contributors to the economy of Sahelian countries, are highly dependent on the rainy season, and very sensitive to small changes in the hydrological cycle (Lebel et al. 2003). The characteristics of the rainy season, however, are not stationary through time, and can even vary greatly on interannual and interdecadal timescales. During the twentieth century, extreme variations in rainfall were observed on a decadal timescale, with a wet period in the 1950s and 1960s preceding a period of extreme droughts in the 1970s and 1980s, before wetter condi-

*Corresponding author: adeline.bichet@univ-grenoblealpes.fr tions returned after the late 1990s (e.g. Lebel \& Ali 2009, Nicholson 2013, Evan et al. 2015, Giannini 2015, Maidment et al. 2015, Sanogo et al. 2015).

Such extreme variations have important consequences for populations and for the development of Sahelian countries. They are often associated with extreme hydro-climate events such as extreme floods and droughts, and often lead to losses of lives, population displacement, damage to infrastructure, and disastrous perturbations for water management and agriculture. In addition, crop growth is extremely sensitive to the occurrence and duration of dry and wet spells (sequences of days with rainfall above or below a given threshold), especially at the beginning and during the rainy season (Gornall et al. 2010). The benefit for society of the Sahelian recent 'rainfall return' is still unclear, as the associated hydro-climate characteristics are still poorly documented. This is partly due to a lack of long-term, high-resolution in situ observa-

() The authors 2018. Open Access under Creative Commons by Attribution Licence. Use, distribution and reproduction are unrestricted. Authors and original publication must be credited.

Publisher: Inter-Research · www.int-res.com 
tions (e.g. Lebel \& Ali 2009, Sanogo et al. 2015) and poor model representation of the West African Monsoon system (e.g. Yaro \& Hesselberg 2016).

Beck \& Grieser (2007) used a global data set of gridded precipitation observations to compare changes in rainfall between the subintervals 1951-1975 and 1976-2000, and found significant negative trends in precipitation and significant increases in drought severity in sub-Saharan regions. However, in the early 2000s, most of the West African countries were struck by floods of unprecedented magnitude (e.g. Ouagadougou in 2009 and Niamey in 2010 and 2012; Sighomnou et al. 2013), and storm intensity is reported to be increasing in the West African Sahel (Taylor et al. 2017).

To better anticipate the consequences for society of the recent rainfall return, we propose to take advantage of a new high-resolution rainfall dataset covering West Africa over 1981-2014 to characterize the changes in hydro-climate conditions in the West African Sahel since 1981.

\section{DATA AND METHODS}

\subsection{Dataset}

We used the Climate Hazards Group Infrared Precipitation with Station data (CHIRPS) rainfall dataset, which is explicitly designed for monitoring agricultural drought and global environmental change over land. It corresponds to a gridded, quasi-global $\left(50^{\circ} \mathrm{S}-50^{\circ} \mathrm{N}\right)$, high-resolution $\left(0.05^{\circ}\right)$, daily rainfall dataset that covers the time period 1981-2014 (Funk et al. 2015). The methodology used to construct this dataset makes it fall somewhere between heavily curated interpolated gauge datasets like that of the Global Precipitation Climatology Centre (GPCC) and sparse gauge plus satellite products like the Rainfall Estimation (RFE2) algorithm. CHIRPS was validated using various rainfall observation data, and the results indicate good performance for drought monitoring (Badr et al. 2016, Herold et al. 2017).

In addition, we validated the CHIRPS dataset for intra-seasonal analysis of daily rainfall patterns in the West African Sahel by comparing some of our results with near-surface daily rain gauge data extracted from the updated BADOPLUS database described by Panthou et al. (2012). Nine stations were selected based on the availability of data over the period of interest (1981-2014), and the homogeneous distribution of the stations across the region. Fig. 1 shows the location of these 9 stations (red crosses): Niamey Air- port $\left(13.47^{\circ} \mathrm{N}, 2.16^{\circ} \mathrm{E}\right), \quad$ Ouagadougou Airport $\left(12.35^{\circ} \mathrm{N}, 1.52^{\circ} \mathrm{W}\right)$, Dakar-Yoff $\left(14.72^{\circ} \mathrm{N}, 17.51^{\circ} \mathrm{W}\right)$, Podor $\left(16.62^{\circ} \mathrm{N}, 14.97^{\circ} \mathrm{W}\right)$, Ziguinchor $\left(12.56^{\circ} \mathrm{N}\right.$, $\left.16.27^{\circ} \mathrm{W}\right)$, Agadez $\left(16.95^{\circ} \mathrm{N}, 7.98^{\circ} \mathrm{E}\right)$, Hombori $\left(15.27^{\circ} \mathrm{N}, 1.70^{\circ} \mathrm{W}\right)$, Kayes $\left(14.43^{\circ} \mathrm{N}, 11.43^{\circ} \mathrm{W}\right)$, Bamako Senou Airport $\left(12.52^{\circ} \mathrm{N}, 7.94^{\circ} \mathrm{W}\right)$.

\subsection{Methodology}

We considered the West African Sahel over the region covering $12.5-17.5^{\circ} \mathrm{N}, 18^{\circ} \mathrm{W}-10^{\circ} \mathrm{E}$ (Fig. 1) and focused our study on the rainy season, JJAS.

We define a wet (dry) day when precipitation is above (below) $1 \mathrm{~mm} \mathrm{~d}^{-1}$ (Sivakumar 1992, Froidurot \& Diedhiou 2017). We define an isolated wet (dry) day as when a single wet (dry) day is preceded and followed by a dry (wet) day. We define a wet (dry) spell when 2 or more consecutive wet (dry) days are preceded and followed by a dry (wet) day. Therefore, the duration of a wet (dry) spell, as defined in our study, spans from 2 to $122 \mathrm{~d}$. Note that unlike other studies (e.g. Salack et al. 2016), this definition of wet (dry) spells does not distinguish between short and long spells. Instead, we follow the definition of Giorgi et al. (2011), where the average dry spell length (DSL) is computed as follows:

$$
\text { DSL }=\text { NDDDS / NDS }
$$

where DSL corresponds to the average duration of dry spells during JJAS, NDDDS is the total number of dry days during JJAS excluding isolated dry days, and NDS corresponds to the total number of dry spells during JJAS. We chose to investigate the aver-

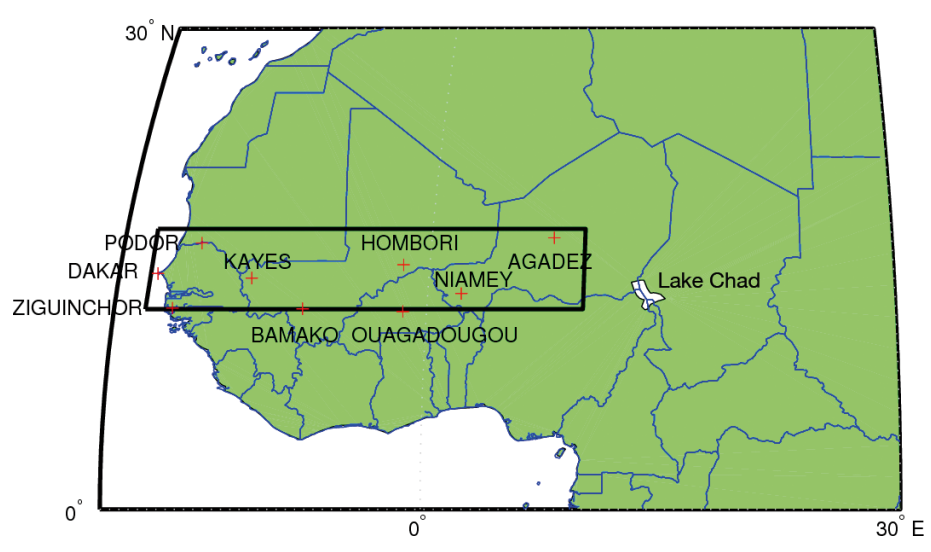

Fig. 1. West African Sahelian region considered for this study $\left(12.5-17.5^{\circ} \mathrm{N}, 18^{\circ} \mathrm{W}-10^{\circ} \mathrm{E}\right)$, represented as the smaller black box. The location of the 9 daily rain gauge stations used for comparison are represented as red crosses 
age dry spell length rather than any other definition of dry spells, in order to be consistent with Giorgi et al. (2011), who used this definition of dry spell to compute the hydrological cycle intensity. Similar calculations were made to determine the average wet spell length.

Finally, we computed the precipitation intensity (simple precipitation intensity index, SDII) and the total number of wet days (annual count of days when precipitation is $>1 \mathrm{~mm}, \mathrm{RR} 1$ ) following the methodology described by the Expert Team of Climate Change Detection and Indices (ETCCDI; Zhang et al. 2011). Note that following the ETCCDI description, SDII corresponds to the precipitation averaged over wet days. Hence, SDII is the precipitation accumulated over wet days divided by the number of wet days. This implies that the value of precipitation intensity in our study translates directly into the intensity of wet events, regardless of the number of wet days.

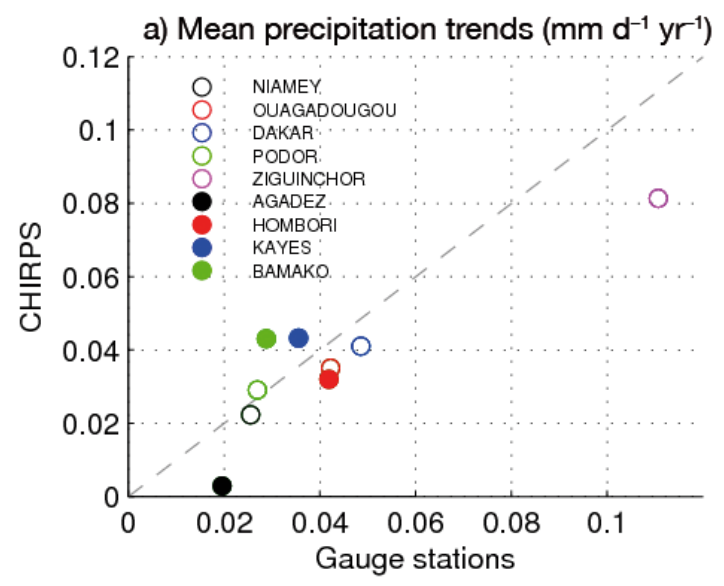

c) Precipitation intensity trends $\left(\mathrm{mm} \mathrm{d}^{-1} \mathrm{yr}^{-1}\right)$

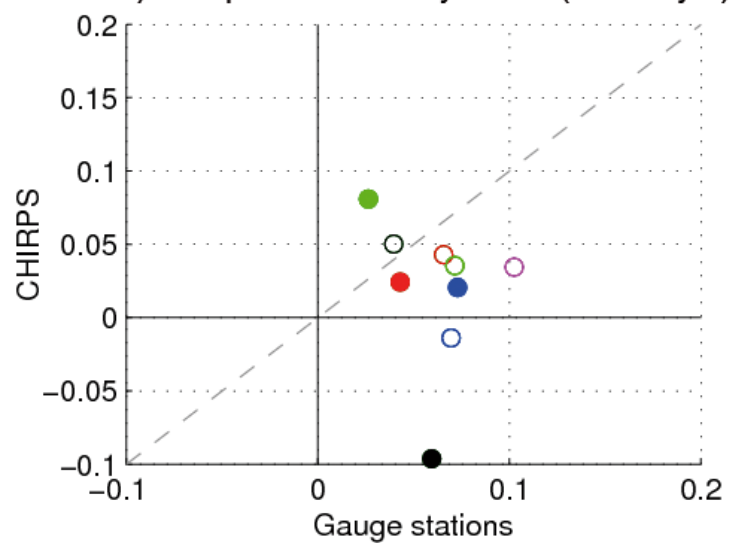

\section{RESULTS}

\subsection{Comparison with daily rain gauges}

Fig. 2 shows the JJAS trends (1981-2014) for mean precipitation $\left(\mathrm{mm} \mathrm{d}^{-1} \mathrm{yr}^{-1}\right)$, number of rainy days $\left(\mathrm{d} \mathrm{yr}^{-1}\right)$, precipitation intensity $\left(\mathrm{mm} \mathrm{d}^{-1} \mathrm{yr}^{-1}\right)$, and average dry spell length $\left(\mathrm{d} \mathrm{yr}^{-1}\right)$, as computed for the 9 daily rain gauges and the 9 corresponding nearest grid points in the CHIRPS data. In Fig. 2a, both datasets show a positive trend in mean precipitation at all 9 locations. The magnitude of the trends is similar in both datasets. In Fig. 2b, both datasets show a positive trend in the total number of wet days (RR1) at all 9 locations. In most locations, this trend is slightly overestimated in the CHIRPS dataset. According to Fig. 2c, both datasets show a positive trend in precipitation intensity (SDII) at 7 locations, with the CHIRPS data slightly underestimating the trends of the rain gauge data. Disagreements occur

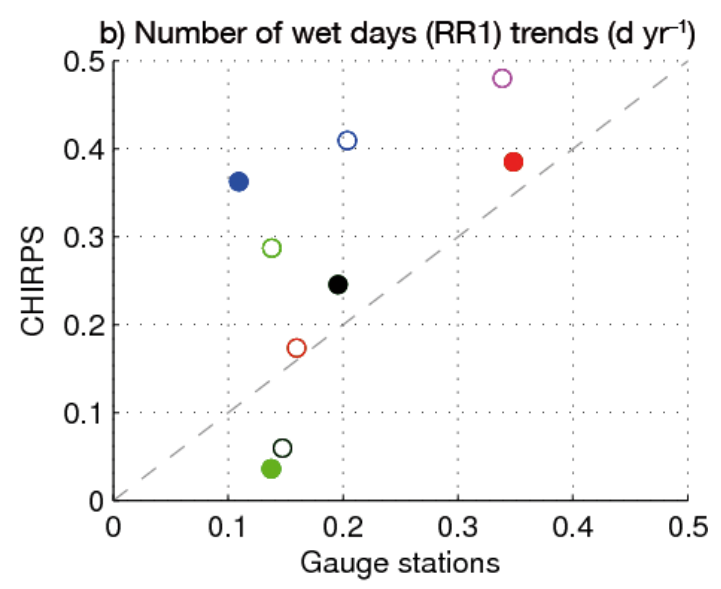

d) Average dry spell trends $\left(\mathrm{d} \mathrm{yr}^{-1}\right)$

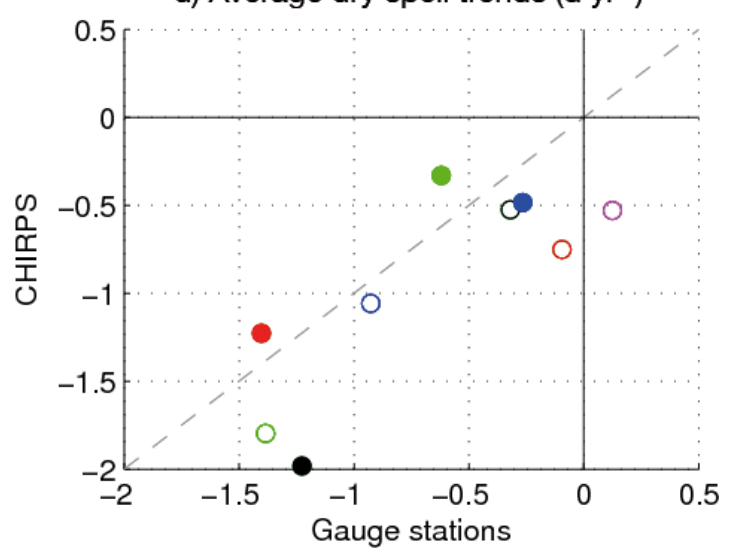

Fig. 2. Comparison of the JJAS trends (1981-2014) for (a) mean precipitation, (b) number of rainy days, (c) precipitation intensity, and (d) average dry spell length, as computed for the 9 daily rain gauge stations (see Fig. 1) and the corresponding nearest grid points in the CHIRPS dataset 
in Dakar and Agadez, where the rain gauge data show an increase in precipitation intensity and the CHIRPS data show a decrease. According to Fig. 2d, both datasets show a negative trend in the average length of dry spells at all 9 locations, with the CHIRPS data slightly overestimating the trends of the rain gauge data. Disagreement occurs in Ziguinchor, where the rain gauge data show an increasing trend and the CHIRPS data show a decrease.

Therefore, except for a few disagreements, both datasets generally agree on the sign and to some extent on the magnitude of the trends in mean precipitation, precipitation intensity, total number of wet days, and average length of dry spells, at the 9 locations selected. Both datasets show a tendency towards wetter conditions over these 9 locations, which is reflected in more frequent and more intense rainfall (except over Dakar and Agadez in the CHIRPS dataset), accompanied by dry spells of shorter average duration.

\subsection{Precipitation trends}

Fig. 3 shows the JJAS trends of precipitation and precipitation intensity over the West African Sahel, in $\mathrm{mm} \mathrm{d}^{-1}$ over the entire period (1981-2104). Precipitation has increased on average by $+0.8 \mathrm{~mm} \mathrm{~d}^{-1}$ over the entire region, reaching up to $+2 \mathrm{~mm} \mathrm{~d}^{-1}$ over the southern and western parts of the region (Senegal, western Mali, southern Mali/northern Burkina, and northwestern Nigeria) since 1981 (Fig. 3a). According to Fig. $3 b$, precipitation intensity has increased by up to $+3 \mathrm{~mm} \mathrm{~d}^{-1}$ over the southern-central part of the West African Sahel, and decreased by up to $5 \mathrm{~mm}$ $\mathrm{d}^{-1}$ over Senegal and eastern Mali/western Niger. Note that over Dakar (Senegal) and Agadez (western Niger), the 2 rain gauges selected for validation (see Section 3.1) indicate an increase in precipitation intensity. Therefore, our results show that in most of the West African Sahel, and in particular over its southern-central part, the precipitation increase observed since 1981 results at least partly from an increase in precipitation intensity (more intense rainfall events). Over Senegal and eastern Mali/western Niger, however, another process must be involved to explain the increase in mean precipitation in the CHIRPS data, as precipitation intensity decreases.

\subsection{Distribution of wet events}

Fig. 4 shows the JJAS trends of the total number of wet days, the total number of isolated wet days, the total number of wet spells, and the average length of wet spells over 1981-2014. The total number of wet days, wet isolated days, and wet spells represent the total number of days accumulated over JJAS. The average length of wet spells represents the average length of spells over JJAS (in percentage as com-

\section{a) Precipitation $\left(\mathrm{mm} \mathrm{d}^{-1}\right)$}

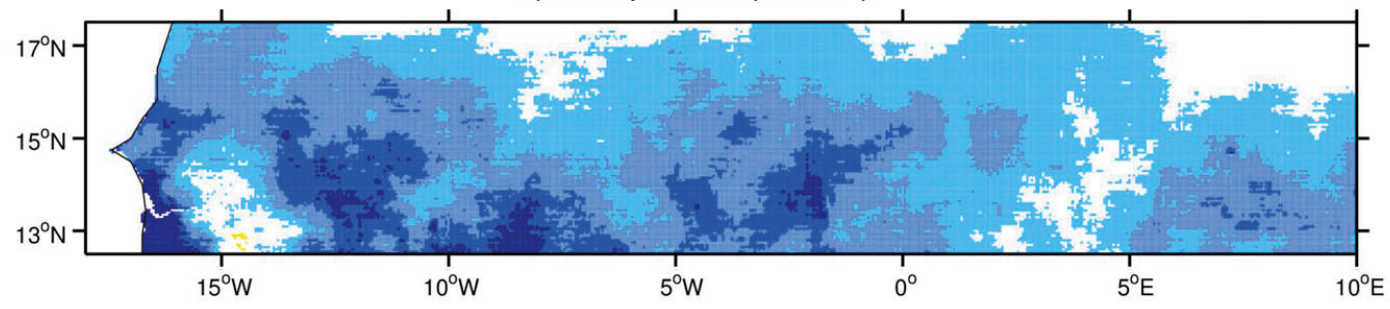

b) Precipitation intensity $\left(\mathrm{mm} \mathrm{d}^{-1}\right)$

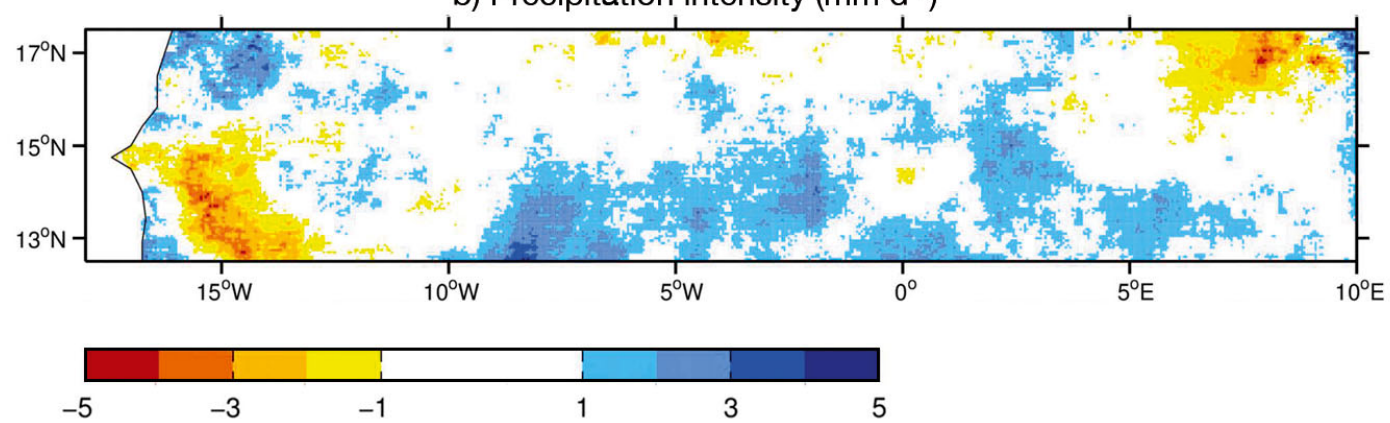

Fig. 3. Trend maps (1981-2014) for (a) precipitation and (b) precipitation intensity, as averaged over JJAS for the West African Sahelian region considered for this study (see Fig. 1) 

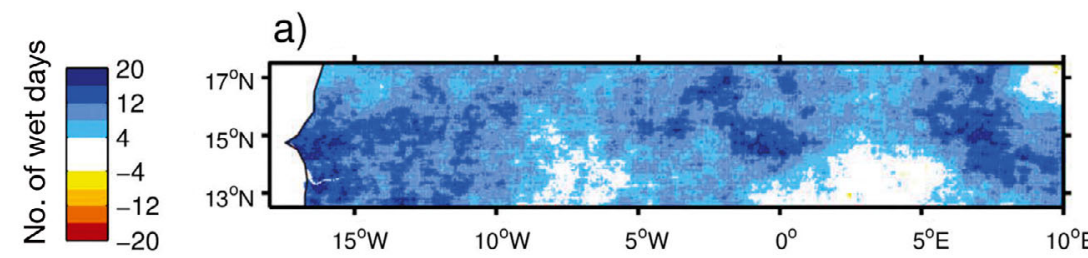

b)
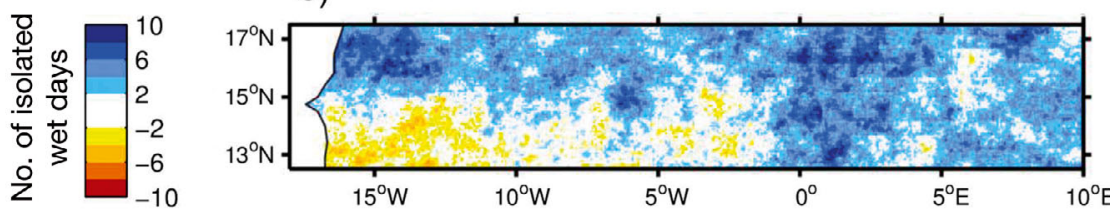

c)
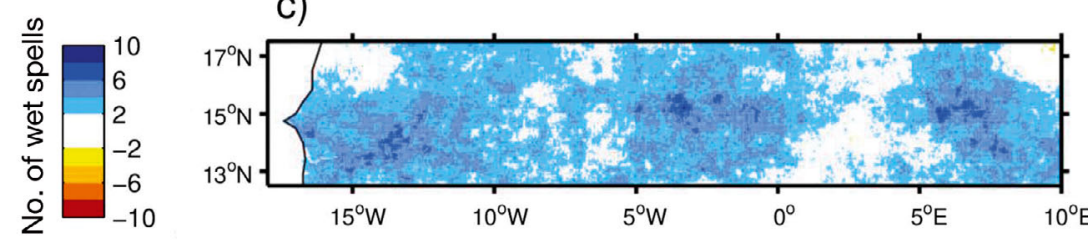

d)
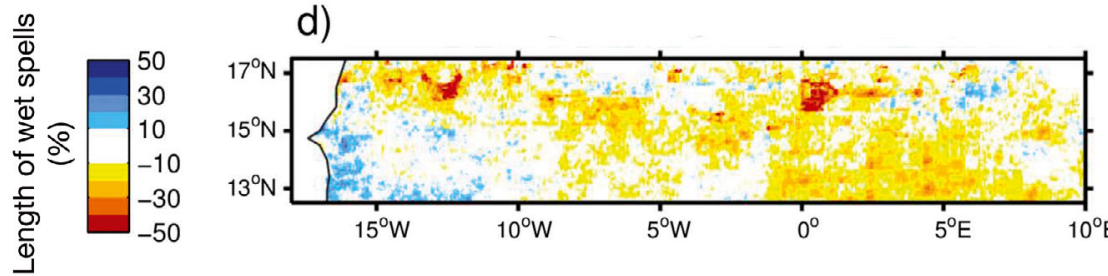

Fig. 4. Trend maps (1981-2014) for the total number of (a) wet days, (b) isolated wet days, and (c) wet spells; (d) average length of wet spells for the West African Sahelian region considered for this study (see Fig. 1)
Niger, our results indicate that in the CHIRPS dataset, the increase in mean precipitation results exclusively from an increase in the total number of wet days, as Fig. 3 shows a decrease in precipitation intensity. In other words, it rains more often, but the rain events bring less rain. In addition, our results show that whereas the number of wet spells has increased over the entire region, the average duration of wet spells is becoming shorter in the central part of the West African Sahel, in favor of more isolated wet days, while in the southwestern part of the West African Sahel, it is getting longer at the expense of fewer isolated wet days.

Fig. 5 shows the JJAS trends of the precipitation intensity averaged over the season during isolated wet days and wet spells, in $\mathrm{mm} \mathrm{d}^{-1}$ for the entire period (1981-2014). Trends in precipitation intensity show a similar spatial pattern during both types of wet events, with an increase over the central part of the West African Sahel and a decrease over Senegal and eastern Mali/western Niger (Fig. 5a,b; see also Fig. 3b). However, the trends are genpared to the average length of wet spells). According to Fig. $4 \mathrm{a}$, the total number of wet days has increased on average by $+9 \mathrm{~d}$ over the entire region, and by up to $+20 \mathrm{~d}$ over the northern (including eastern Mali/ western Niger) and western (including Senegal) parts of the region. This confirms previous studies suggesting that the mean position of the ITCZ has moved northward during the last $30 \mathrm{yr}$ in agreement with the assumption of a return to wetter conditions (Sanogo et al. 2015). Fig. 4b shows that the number of isolated wet days has increased by up to $+10 \mathrm{~d}$ over the northern and eastern parts of the region, but decreased by up to $6 \mathrm{~d}$ over the southwestern part of the region. In addition, whereas the number of wet spells has increased over the entire region (Fig. 4c), the average length of wet spells has decreased by up to $20 \%$ over the northern and eastern parts of the region but increased by up to $+20 \%$ over the southwestern part of the region (Fig. 4d). Hence, our results show that the recent increase in precipitation observed over the West African Sahel in the past $30 \mathrm{yr}$ also results from an increase in the total number of wet days. Over Senegal and eastern Mali/western erally stronger during isolated wet days. In particular, Fig. 5a shows a strong increase in precipitation intensity during isolated wet days, over southern Mali/northern Burkina Faso, suggesting that this region experienced an increasing number of isolated heavy rainfall events which may lead to more occurrences of floods.

\subsection{Distribution of dry events}

Fig. 6 shows the JJAS trends in the total number of dry days, the total number of isolated dry days, the total number of dry spells, and the average length of dry spells over the period 1981-2014. The total number of dry days, dry isolated days, and dry spells represent the total number of days accumulated over JJAS. The average length of dry spells represents the average length of spells over JJAS (in percentage as compared to the average length of dry spells). In agreement with Fig. 4a, Fig. 6a shows that the total number of dry days has decreased on average by $9 \mathrm{~d}$ over the entire region, and by up to $20 \mathrm{~d}$ over the 
a) Isolated wet days

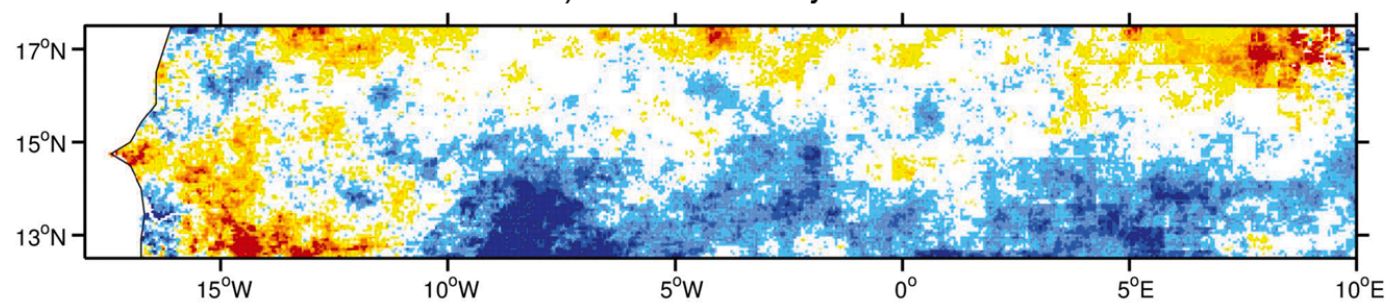

b) Wet spells
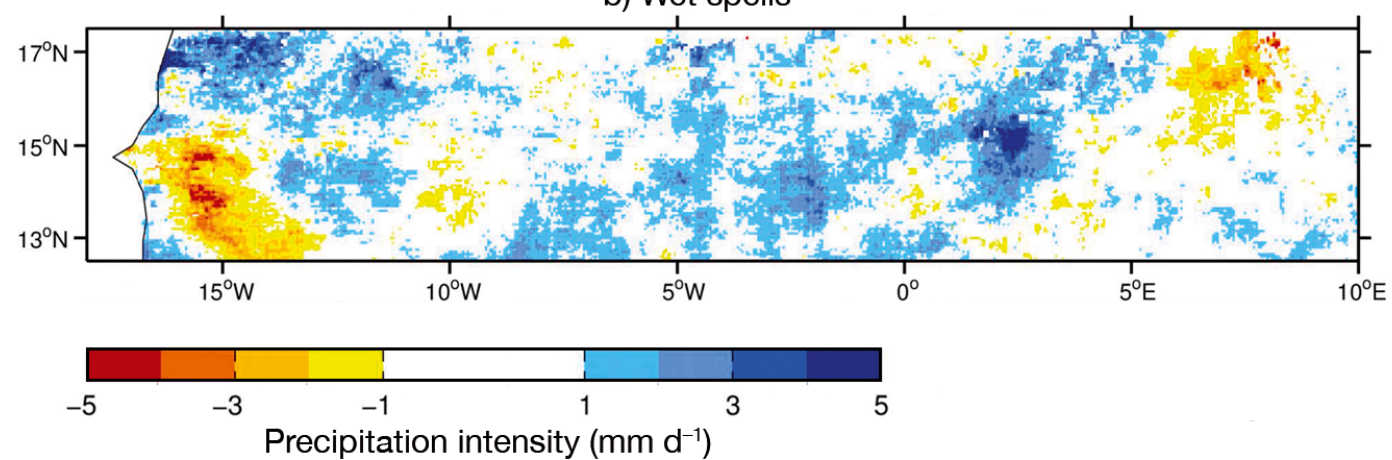

Fig. 5. Trend maps (1981-2014) for precipitation intensity during (a) isolated wet days and (b) wet spells, as averaged over JJAS for the West African Sahelian region considered for this study (see Fig. 1)
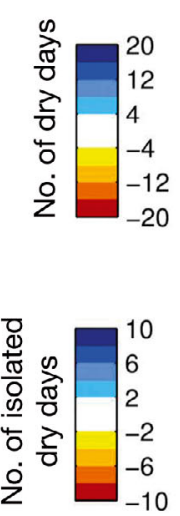

b)

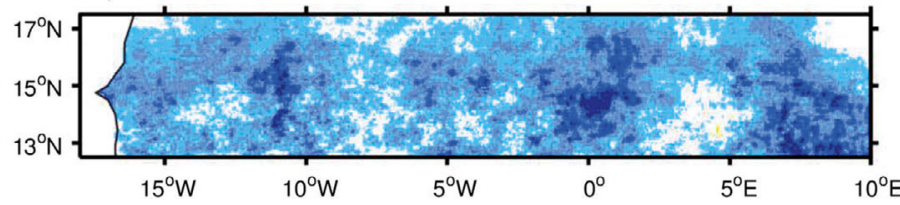

c)

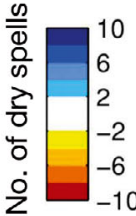

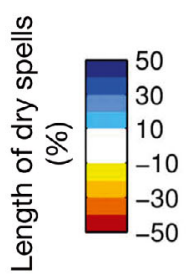

d)

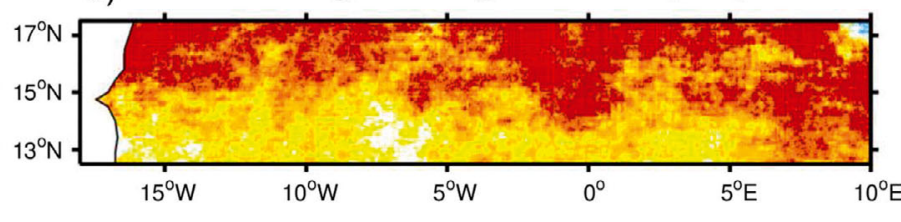

Fig. 6. Trend maps (1981-2014) for the total number of (a) dry days, (b) isolated dry days, and (c) dry spells; (d) average length of dry spells for the West African Sahelian region considered for this study (see Fig. 1) northern and western part of the region. However, whereas the number of isolated dry days has increased over the entire region (Fig. 6b), the number of dry spells has decreased over the southwestern part of the region and increased elsewhere (Fig. 6c). The average length of dry spells has decreased over the entire region (on average by $32 \%$ ), and in particular over the northern part of the region (on average 50\%; Fig. 6d). Additional analyses (not shown) indicate that this shortening of dry spells occurs mostly via a decline in the number of dry spells lasting more than 4 and $7 \mathrm{~d}$, respectively, in the southern and northern part of the region, in favor of dry spells lasting respectively less than 3 and $6 \mathrm{~d}$. Hence, our results show that over the entire West African Sahel band, the average duration of dry spells is getting shorter in favor of more isolated dry days. In addition, the number of dry spells has increased everywhere except over the southwestern part of the region where a slight decrease is noted. 


\section{DISCUSSION AND CONCLUSION}

To summarize, the present study shows that the CHIRPS dataset generally agrees with a selection of 9 daily rain gauge stations, on the sign and to some extent on the magnitude of the trends in mean precipitation (increase), number of wet days (increase), precipitation intensity (increase), and average length of dry spells (decrease). Disagreements regarding the trend sign in precipitation intensity are found over Dakar and Agadez, and highlight the need for further investigations on the agreement across daily observational products for West African Sahel precipitation.

Over Senegal and eastern Mali/western Niger, the CHIRPS dataset shows an increase in mean precipitation since 1981 that results exclusively from an increase in precipitation frequency (precipitation intensity decreases). Elsewhere over the West African Sahel, the CHIRPS dataset shows an increase in mean precipitation since 1981 that results from both an increase in precipitation frequency (dominant over the northern and western part of the region) and an increase in precipitation intensity (dominant over the southern part of the region). Over the southwestern part of the West African Sahel (Senegal included), the increase in precipitation frequency results from more numerous and longer average duration of wet spells (at the expense of isolated wet days) separated by less numerous and shorter average duration of dry spells. Elsewhere over the West African Sahel (eastern Mali/western Niger included), the increase in precipitation frequency results from more numerous isolated wet days and more numerous but shorter average duration of wet spells, separated by more numerous but shorter average duration of dry spells.

Our results agree with Sanogo et al. (2015), who investigated trends over 1980-2010 in rain gauge data and found that the Sahel 'rainfall recovery' is reflected in (1) more rainy days (mostly over northern and western parts of the West African Sahel in our case), (2) an increase in the maximum length of wet spells (increase in the average length of wet spells over the western part of the West African Sahel in our case), and (3) more extreme rainfall events (increase in precipitation intensity over the southern-central part of the West African Sahel in our case). Our results also agree with Panthou et al. (2014), who compared rain gauge data from the periods 19912000 and 2001-2010 and reported an increase in precipitation intensity over the Central Sahel $\left(5^{\circ} \mathrm{W}-7^{\circ} \mathrm{E}\right.$, $9.5-15.5^{\circ} \mathrm{N}$ ), and almost no change in the number of wet days over the southern part of the Central Sahel.
Our results are also in general agreement with Odoulami \& Akinsanola (2015), who analyzed recent changes in the West African monsoon using 2 gridded, satellite-based daily rainfall observations (Global Precipitation Climatology Project [GPCP] and Tropical Rainfall Measuring Mission [TRMM]) over the period 1998-2013, and found an increase in the number of wet days and a decrease in the number of extreme rainfall events over West Africa.

Although our dataset does not allow a comparison with earlier periods, our results do not indicate an increase in drought conditions as suggested by Salack et al. (2016). Aside from a very different approach between the 2 studies (Salack et al. 2016 investigated changes in agro-climatic indices over 1960-2002 with daily rain gauge data and specific cluster classifications), we argue that part of this disagreement comes from the different definition of dry spells in the 2 studies. Whereas Salack et al. (2016) investigated the changes in specific definitions of dry spells (extreme dry spells [longer than $7 \mathrm{~d}$ and longer than $15 \mathrm{~d}$ ], dry spell after onset, and post-floral dry spells), we investigated changes in the average duration of dry spells. Section 3.1 shows that the average duration of dry spells decreases in both the CHIRPS data and the selection of 9 rain gauges. An in-depth comparison would be required to conclude on this issue. Moreover, according to Giorgi et al. (2011), the hydrological cycle intensity is a combination of both the average dry spell length and the precipitation intensity. Although we did not compute this index in our study, we argue that in the CHIRPS data, because the average dry spell length is decreasing over the entire West African Sahel since 1981, the hydrological intensity could only increase as a result of a strong increase in precipitation intensity. Hence, in the CHIRPS dataset, the hydrological cycle intensity may only increase over the southern-central and the northwestern part of West African Sahel (northern Senegal), and definitely decreases over Senegal and eastern Mali/western Niger. From this perspective, our results confirm the intensification of the hydrological cycle as suggested by Taylor et al. (2017), but highlight few subregions in the West African Sahel where a decrease is noted. Again, in light of the disagreement across daily datasets on the trend of precipitation intensity, this issue needs to be further investigated, as understanding the mechanisms leading to the observed changes is beyond the scope of this study.

Nevertheless, potential processes may include global warming (Dong \& Sutton 2015), variations in sea surface temperatures (e.g. Giannini et al. 2003), and organization of the Mesoscale Convective Sys- 
tem (e.g. Mathon et al. 2002, Taylor et al. 2017). Future work is planned to investigate the associated changes in atmospheric circulation and the role of external forcing using regional climate models.

Acknowledgements. The research leading to this publication received funding from the NERC/DFID 'Future Climate for Africa' program under the AMMA-2050 project, grant number NE/M019969/1. We acknowledge the usage of the CHIRPS data set from the Climate Hazards Group (http:// chg.geog.ucsb.edu/data/chirps). Our work has benefited from access to rainfall data sets provided by the AMMACATCH observatory, the AMMA international program, DMN Burkina, ANACIM, and DMN Niger; we sincerely thank all of them, as well as the staff at the IGE computation center (Guillaume Quantin, Véronique Chaffard, Patrick Juen, and Wajdi Nechba) for their technical support, and Geremy Panthou for his role in accessing the data and insights into the dataset.

\section{LITERATURE CITED}

Badr HS, Dezfuli AK, Zaitchik BF, Peters-Lidard CD (2016) Regionalizing Africa: patterns of precipitation variability in observations and global climate models. J Clim 29: 9027-9043

Beck C, Grieser J (2007) Precipitation trends and shifts of rainfall regimes in Africa since 1951. In: Lozán J (ed) Global change: enough water for all? Wissenschaftliche Auswertungen, Hamburg, p 191-194

Dong B, Sutton R (2015) Dominant role of greenhouse-gas forcing in the recovery of Sahel rainfall. Nat Clim Chang 5:757-760

Evan AT, Flamant C, Lavaysse C, Kocha C, Saci A (2015) Water vapour forced greenhouse warming over the Sahara desert and the recent recovery from the Sahelian drought. J Clim 28:108-123

Froidurot S, Diedhiou A (2017) Characteristics of wet and dry spells in the West African monsoon system. Atmos Sci Lett 18:125-131

Funk C, Peterson P, Landsfeld M, Pedreros D and others (2015) The climate hazards infrared precipitation with stations - a new environmental record for monitoring extremes. Sci Data 2:150066

Giannini A (2015) Climate change comes to the Sahel. Nat Clim Chang 5:720-721

Giannini A, Saravanan R, Chang P (2003) Oceanic forcing of Sahel rainfall on interannual to interdecadal time scales. Science 302:1027-1030

Giorgi F, Im ES, Coppola E, Diffenbaugh NS, Gao XJ, Mariotti L, Shi Y (2011) Higher hydroclimate intensity with global warming. J Clim 24:5309-5324

Gornall J, Betts R, Burke E, Clark R, Camp J, Willett K, Wilt-

Editorial responsibility: Filippo Giorgi,

Trieste, Italy shire A (2010) Implications of climate change for agricultural productivity in the early twenty-first century. Philos Trans R Soc B 365:2973-2989

*Herold N, Behrangi A, Alexander LV (2017) Large uncertainties in observed daily precipitation extremes over land. J Geophys Res Atmos 122:668-681

Lebel T, Ali A (2009) Recent trends in the Central and Western Sahel rainfall regime (1990-2007). J Hydrol (Amst) 375:52-64

* Lebel T, Diedhiou A, Laurent H (2003) Seasonal cycle and interannual variability of the Sahelian rainfall at hydrological scales. J Geophys Res 108:8389

*Maidment RI, Allan RP, Black E (2015) Recent observed and simulated changes in precipitation over Africa. Geophys Res Lett 42:8155-8164

Mathon V, Laurent H, Lebel T (2002) Mesoscale convective system rainfall in the Sahel. J Appl Meteorol 41: 1081-1092

Nicholson SE (2013) The West African Sahel: a review of recent studies on the rainfall regime and its interannual variability. ISRN Meteorology 2013:453521

Odoulami RC, Akinsanola AA (2017) Recent assessment of West African summer monsoon daily rainfall trends. Weather 73:27-33

* Panthou G, Vischel T, Lebel T, Blanchet J, Quantin G, Ali A (2012) Extreme rainfall in West Africa: a regional modeling. Water Resour Res 48:W08501

Panthou G, Vischel T, Lebel T (2014) Recent trends in the regime of extreme rainfall in the Central Sahel. Int J Climatol 34:3998-4006

Salack S, Klein C, Giannini A, Sarr B and others (2016) Global warming induced hybrid rainy seasons in the Sahel. Environ Res Lett 11:104008

* Sanogo S, Fink AH, Omotosho JA, Ba A, Red R, Ermert V (2015) Spatio-temporal characteristics of the recent rainfall recovery in West Africa. Int $\mathrm{J}$ Climatol 35: 4589-4605

Sighomnou D, Descroix L, Genthon P, Mahé G and others (2013) La crue de 2012 a Niamey: un paroxysme du paradoxe du Sahel? Sécheresse 24:3-13

Sivakumar MVK (1992) Empirical analysis of dry-spells for agricultural applications in West Africa. J Clim 5: 532-539

Sultan B, Janicot S, Diedhiou A (2003) The West African monsoon dynamics. I. Intraseasonal variability. J Clim 16:3389-3406

Taylor CM, Beluši D, Guichard F, Parker DJ and others (2017) Frequency of extreme Sahelian storms tripled since 1982 in satellite observations. Nature 544:475-478

*Yaro JA, Hesselberg J (2016) Adaptation to climate change and variability in rural West Africa. Springer International Publishing, Basel

Khang X, Alexander LV, Hegerl GC, Jones P and others (2011) Indices for monitoring changes in extremes based on daily temperature and precipitation data. Wiley Interdiscip Rev Clim Change 2:851-870

Submitted: October 30, 2017; Accepted: April 4, 2018

Proofs received from author(s): June 19, 2018 